\title{
Baculovirus Expression System
}

National Cancer Institute

\section{Source}

National Cancer Institute. Baculovirus Expression System. NCI Thesaurus. Code C19553.

An insect cell-infecting virus that is used extensively in expression systems for recombinant proteins that require eucaryotic processing systems. 